\title{
ALTERNATIF SISTEM SADAP KLON RRIC 100 MULAI BUKA SADAP
}

\author{
Alternative Tapping Systems for RRIC 100 Clone from the Opening \\ Eva HERLINAWATI dan KUSWANHADI \\ Balai Penelitian Sembawa, Pusat Penelitian Karet \\ Jalan Raya Palembang P. Balai KM 29, PO BOX 1127 Palembang 30001 \\ Email : eva_herlinawati@yahoo.com
}

Diterima tanggal 10 Mei 2013 / Disetujui tanggal 13 September 2013

\begin{abstract}
Ethephon or gas stimulant is commonly used in rubber cultivation especially in commercial estates. The use of stimulation should be associated with reduction of tapping intensity by shortening the cut length. The purpose of this study was to compare and evaluate the effects of various tapping systems on production and physiology characters in the opening. The experiment was carried out in the experimental field of Sembawa Research Station from March to Desember 2011. The experiment was arranged in a completely randomized block design with six treatments and eight replications. The experiment used RRIC 100 clone planted in 2004. The treatments were $S / 2 d 3$, S/2 d3 ET2.5\% Ga1 12/y (m), S/2 d3 ET2.5\% Ga1 24/y (2w), Sc20 Ud3 ETG 12/y(m), Sc20 Ud3 ETG 24/y(2w), and Sc2O U d3 ET2.5\% Ba1 24/y(2w). The results showed that the tapping system of $S / 2$ d3 ET2.5\% Ga 1 12/y (m) or Sc2O U d3 ETG 12/y(m) could increase production without negative effect on physiological characters. However, the application of gas stimulant on young trees should consider the risk of tapping panel dryness. Since the upward tapping tends to cause a thicker-bark cut and latex spillage over the groove, the tapper should be well trained.
\end{abstract}

Keywords: Tapping system, RRIC 100, opening, ethylene, ethephon, short tapping, gas stimulation

\section{Abstrak}

Stimulan etefon atau gas telah umum digunakan pada perkebunan, khususnya di perkebunan besar. Penggunaan stimulan harus dikombinasikan dengan penurunan intensitas penyadapan melalui pengurangan panjang irisan sadap. Penelitian ini bertujuan untuk membandingkan dan mengevaluasi pengaruh berbagai sistem sadap terhadap produksi dan parameter fisiologi sejak buka sadap. Penelitian dilaksanakan di Kebun Percobaan Balai Penelitian Sembawa mulai Maret sampai Desember 2011. Penelitian disusun berdasarkan Rancangan Acak Kelompok dengan 6 perlakuan sistem sadap dan 8 ulangan, menggunakan klon
RRIC 100 tahun tanam 2004. Perlakuan antara lain S/2 d3, S/2 d3 ET2,5\% Ga1 12/y (m), s/2 d3 ET2,5\% Ga1 24/y (2w), Sc20 U d3 ETG 12/y(m), Sc20 U d3 ETG 24/y(2w), dan Sc20 U d3 ET2,5\% Ba1 24/y(2w). Hasil penelitian menunjukkan sistem sadap S/2 d3 ET2,5\% Ga1 12/y (m) atau Sc20 U d3 ETG 12/y(m) mampu meningkatkan produksi tanpa menimbulkan pengaruh negatif terhadap karakter fisiologi. Namun demikian, penggunaan stimulan gas pada tanaman muda perlu pertimbangan risiko kering alur sadap. Penyadapan ke arah atas memiliki kecenderungan lebih tebal dalam konsumsi kulit dan tumpahnya lateks dari alur sadap, karena itu penyadap sebaiknya dilatih dengan baik.

Kata kunci : Sistem sadap, RRIC 100, buka sadap, etilen, etefon, irisan pendek, stimulan gas

\section{PENDAHULUAN}

Masalah utama dalam perkebunan karet adalah kurangnya tenaga kerja yang terampil untuk memanen lateks dan tingginya biaya tenaga kerja. Kondisi ini mendorong peningkatan biaya produksi per unit area. Oleh karena itu, peningkatan efisiensi dalam sistem eksploitasi merupakan suatu usaha untuk mengoptimalkan keuntungan. Salah satu cara adalah dengan aplikasi stimulan yang berupa etefon ataupun gas etilen. Penggunaan stimulan dapat meningkatkan produksi lateks dengan memperlama aliran lateks, akibat penyumbatan pembuluh lateks yang terhambat (Jacob et al., 1989; Wargadipura, 1981; Krishnakumar et al., 2011; Gomez, 1983). Begitu juga dengan ketidakstabilan lutoid dapat berkurang dengan penggunaan stimulan (Coupe and Chrestin, 1989). Hal tersebut akan mempengaruhi metabolisme sel lateks sebagai yang tampak dari karakter fisiologi seperti sukrosa, fosfat anorganik, tiol, dan kadar karet kering (d'Auzac dan Jacob, 1984; Gohet et al., 2008). 
Cara eksploitasi tanaman karet yang umum dilakukan selama ini adalah irisan standar (S/2) dengan sadapan ke arah bawah (SKB) yang dikombinasikan dengan stimulan. Sivakumaran et al. (1985) dan Junaidi dan Kuswanhadi (1997) melaporkan bahwa sadapan ke arah bawah dapat membatasi aliran asimilat dengan daerah drainase. Hal ini mengakibatkan kurang lancarnya suplai bahan asimilat untuk proses regenerasi lateks sehingga menyebabkan semakin rendahnya respon tanaman terhadap SKB. Pembatasan aliran drainase akan semakin meningkat ketika irisan sadap mendekati pertautan okulasi. Di samping itu, sadapan ke arah bawah seringkali mengakibatkan timbulnya kering alur sadap.

Berdasarkan fakta tersebut, timbul pemikiran untuk mengubah arah sadap dari sadapan ke arah bawah menjadi sadapan ke arah atas sejak buka sadap. Sadapan ke arah atas pada klon GT 1 dan RRIM 600 dapat meningkatkan produksi hingga 54\% pada tahun pertama sadap (Sivakumaran et al., 1985). Selain itu, Lukman (1995) melaporkan bahwa sadapan ke arah atas pada klon GT 1 meningkatkan produksi sebesar $34-46 \%$ di atas sadapan ke arah bawah. Junaidi dan Kuswanhadi (1995) menyatakan respons klon terhadap sadapan ke arah atas berbeda antar klon. Dengan sistem sadap ini, hubungan antara bidang sadap dan tajuk tanaman tetap terpelihara, sehingga gejala penyumbatan/blockage dapat dihindari dan aliran asimilat lebih efektif (D'Auzac dan Jacob, 1984). Selain itu, aliran lateks pada sadapan ke arah atas akan meningkat dengan dukungan gaya gravitasi (Junaidi dan Kuswanhadi, 1997).
Penerapan sadapan ke arah atas harus dikombinasikan dengan aplikasi stimulan dan irisan pendek. Dengan irisan pendek dapat memperpanjang siklus ekonomi tanaman karet dan meningkatkan produktivitas penyadap (Obouyeba et al., 2008). Di sisi lain, dengan irisan pendek, tekanan turgor dan gradient pada sel lateks lebih dipertahankan dan tidak terjadi pembatasan daerah drainase (Southorn dan Gomez, 1970).

Penelitian ini bertujuan untuk membandingkan dan mengevaluasi pengaruh berbagai sistem sadap terhadap produksi dan karakter fisiologi sejak buka sadap. Sistem sadap yang optimum akan memberikan produksi tertinggi tanpa menimbulkan efek negatif terhadap kesehatan tanaman.

\section{BAHAN DAN METODE}

Penelitian dilaksanakan di Kebun Percobaan Balai Penelitian Sembawa mulai Maret sampai Desember 2011. Penelitian disusun berdasarkan Rancangan Acak Kelompok dengan 6 perlakuan sistem sadap dan 8 ulangan. Percobaan menggunakan klon RRIC 100 tahun tanam 2004. Perlakuan adalah sebagai berikut (Gambar 1):

1. $\mathrm{S} / 2 \mathrm{~d} 3$

2. $\mathrm{S} / 2 \mathrm{~d} 3 \mathrm{ET} 2,5 \% \mathrm{Ga} 112 / \mathrm{y}(\mathrm{m})$

3. S/2 d3 ET $2,5 \%$ Ga $124 / y(2 w)$

4. Sc20 U d3 ETG $12 / \mathrm{y}(\mathrm{m})$

5. Sc20 U d3 ETG $24 / y(2 w)$

6. Sc20 U d3 ET2,5\% Ba1 24/y(2w)

Aplikasi stimulan gas dipasang pada setiap pohon (perlakuan 4 dan 5) dengan cara sebagai berikut : bidang sadap dibagi menjadi 4 bagian (S/4). Aplikator gas
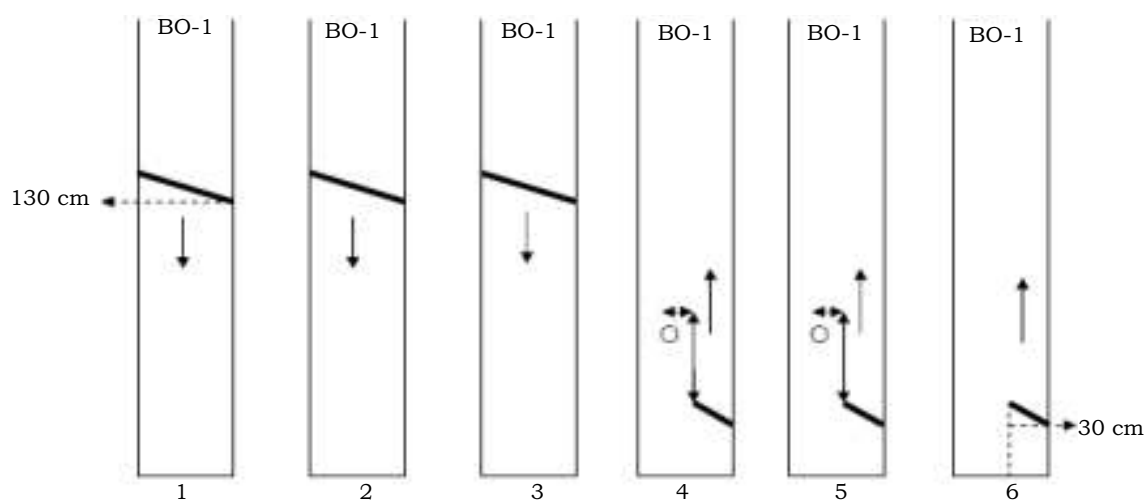

Gambar 1. Posisi panel sadap dengan perbedaan sistem sadap ( $0=$ aplikator gas $)$

Figure 1. Position of tapping panels at different tapping systems $(0=$ gas applicator $)$ 
dipasang pada posisi $20-30 \mathrm{~cm}$ di atas bidang sadap dan $5-7 \mathrm{~cm}$ ke kiri. Gas etilen dimasukkan dengan membuka katup pada selang aplikator dan gas tersebut akan ditampung dalam kantong penampung gas sebelum diserap oleh tanaman.

Produksi karet ditimbang sebagai lump mangkok dari masing-masing pohon setiap tiga hari sadap. Kadar karet kering (KKK) diukur dengan metode gravimetri, berdasarkan perbandingan \% bobot kering dengan bobot basah lateks sebanyak 5 gram. Pengeringan dilakukan dengan oven suhu $100^{\circ} \mathrm{C}$ hingga bobotnya tetap.

Kadar sukrosa dan fosfat anorganik diukur di laboratorium dengan menggunakan spektrofotometer setiap 3 bulan, masing-masing absorbansi diukur pada panjang gelombang 627, 750, dan $412 \mathrm{~nm}$. Setiap sampel lateks $(1 \mathrm{ml})$ dipreparasi ke dalam $9 \mathrm{ml}$ TCA 2,5\% (asam trikloro asetat) dan disaring menjadi serum TCA. Pengukuran kadar sukrosa lateks menggunakan metode anthrone (Dische, 1962). Kadar fosfat anorganik didasarkan pada pengikatan oleh ammonium molibdat yang kemudian tereduksi oleh $\mathrm{FeSO}_{4}$ dalam reaksi asam (Taussky dan Shorr, 1953).

Pengamatan persentase kering alur sadap (KAS) dilakukan secara visual, kemudian diubah dengan penilaian skor sebagai berikut :

0 = tidak terjadi KAS

$1=1-25 \%$ alur sadap kering

$2=26-50 \%$ alur sadap kering

$3=51-75 \%$ alur sadap kering

$4=76-100 \%$ alur sadap kering

\section{HASIL DAN PEMBAHASAN}

Penggunaan stimulan etefon pada sistem sadap konvensional (S/2 ET2,5\%) meningkatkan produksi menjadi 146,2 $165,2 \%$ (perlakuan 2 dan 3 ) dibanding kontrol (perlakuan 1) (Gambar 2). Namun peningkatan frekuensi stimulan etefon dari sekali per bulan menjadi dua kali per bulan tidak meningkatkan produksi. Sementara dengan sistem sadap yang lain yaitu kombinasi irisan pendek dengan stimulan gas meningkatkan produksi menjadi $154,3 \%$ - 165,8\% (perlakuan 4 dan 5), dan kombinasi irisan pendek dengan stimulan etefon hanya mampu meningkatkan produksi menjadi $123,9 \%$ (perlakuan 6).

Berdasarkan hasil di atas terlihat bahwa dengan memperpendek panjang irisan sadap dari $\mathrm{S} / 2$ menjadi Sc20 dan dengan mengubah arah sadapan dari sadapan ke arah bawah (SKB) menjadi sadapan ke arah atas (SKA), maka produksi

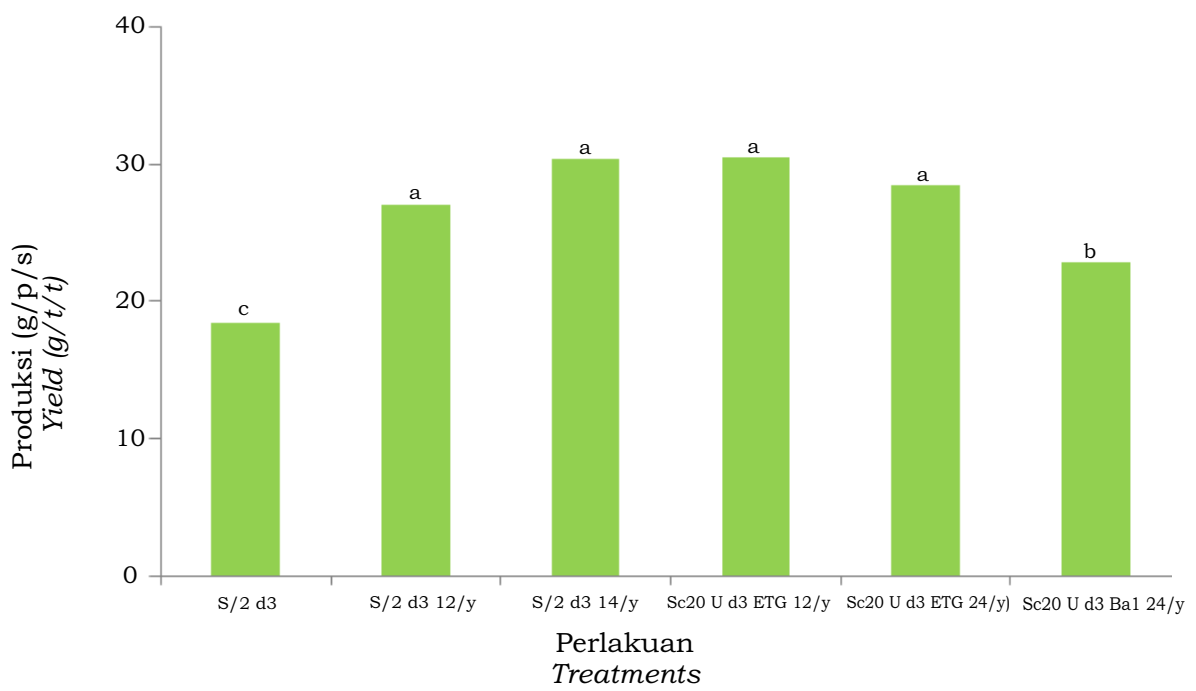

Angka yang diikuti huruf sama pada kolom sama menunjukkan tidak beda nyata pada taraf signifikasi $5 \%$ Figures followed by the same letter in the same column, are not signigicantly different at $5 \%$

Gambar 2. Produksi pada berbagai sistem sadap

Figure 2. Yield at various tapping systems 
relatif sama dengan $\mathrm{S} / 2$ SKB menggunakan stimulan etefon. Dengan irisan pendek mampu untuk menghemat konsumsi kulit tanpa menurunkan produksi, sehingga dapat memperpanjang siklus ekonomi tanaman. Namun, kombinasi irisan pendek SKA dengan stimulan etefon mempunyai produksi yang lebih rendah dibandingkan dengan kombinasi irisan pendek SKA dengan stimulan gas. Kondisi ini menunjukkan kombinasi irisan pendek SKA lebih sesuai dengan stimulan gas.

Perlakuan setengah spiral menggunakan etefon dan kombinasi irisan pendek dengan etefon atau gas efektif meningkatkan produksi dengan cara memperlama aliran lateks. Aliran lateks yang lebih lama ini merupakan akibat peningkatan kestabilan lutoid yang menunda proses penyumbatan pembuluh lateks. Parameter yang erat hubungannya dengan aliran lateks adalah kadar karet kering (KKK) (Jacob et al., 1989; Wargadipura, 1981; Krishnakumar et al., 2011; Coupe dan Chrestin, 1989). KKK dan produksi memiliki korelasi negatif (Gambar 4A), artinya produksi yang tinggi akan diikuti dengan penurunan KKK. Hal tersebut serupa dengan hasil penelitian yang telah dilakukan oleh Van Gils (1951). KKK pada stimulan etefon atau gas menunjukkan penurunan yang bervariasi (Gambar 2). Penurunan KKK tersebut masih dalam batasan normal (> 30\%) yang mencermin- kan regenerasi lateks belum terganggu. Stimulan mampu mengurangi hambatan aliran lateks melalui reaksi pengenceran (dilution reaction) (Jacob et al., 1989). Mekanisme reaksi pengenceran adalah mengurangi viskositas dan meningkatkan pengenceran (Pakianathan et al., 1989).

Sementara pengaruh regenerasi lateks akan tercermin pada fosfat anorganik dan sukrosa. Secara umum, perlakuan setengah spiral dengan etefon dan kombinasi irisan pendek dengan etefon ataupun gas meningkatkan kadar fosfat anorganik (Gambar 3). Peningkatan fosfat anorganik menunjukkan peningkatan aktivitas metabolisme dalam sel lateks (Jacob et al., 1989; Soumahin et al., 2009). Hubungan antara fosfat anorganik dengan produksi bersifat positif (Gambar 4C), namun fosfat anorganik dan sukrosa mempunyai korelasi negatif (Gambar 4B) karena peningkatan metabolisme diikuti dengan peningkatan konsumsi sukrosa (Gohet et al., 2008). Sementara hubungan antara hasil dengan sukrosa juga memiliki korelasi negatif (Gambar 4D). Peningkatan frekuensi etefon dari sekali perbulan menjadi dua kali per bulan tidak mampu meningkatkan produksi dan fosfat anorganik, namun menurunkan kadar sukrosa hingga mencapai level $4 \mathrm{mM}$.

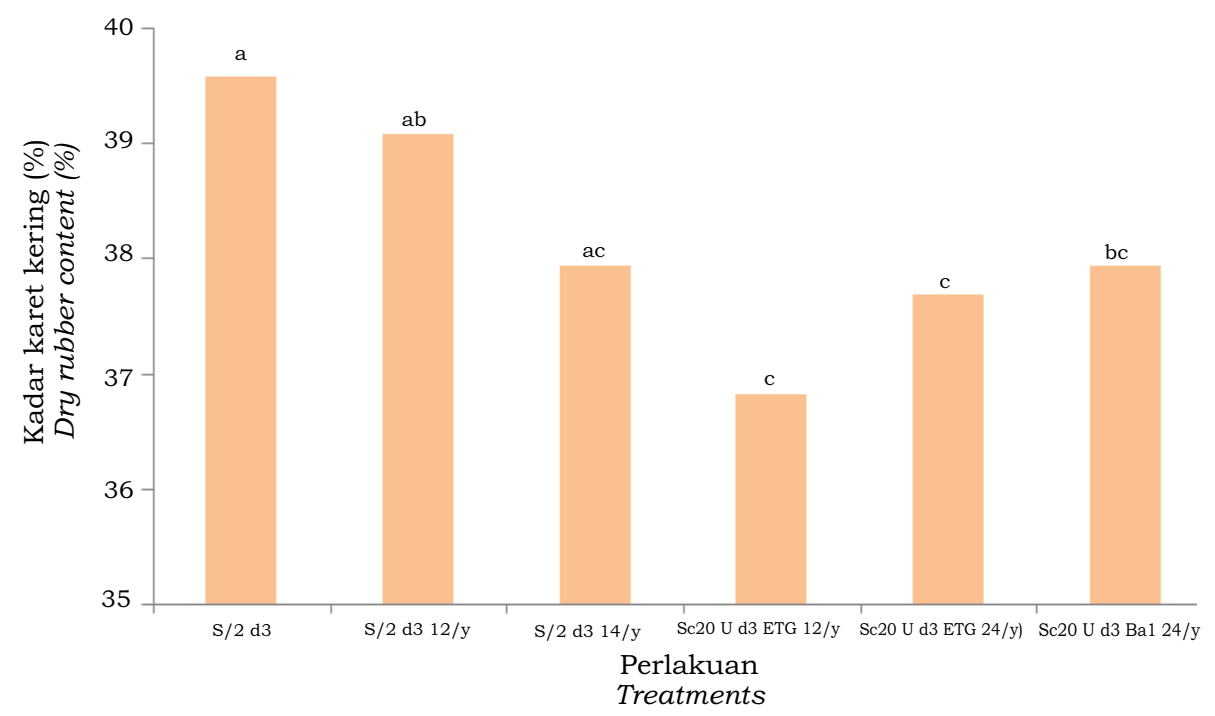

Angka yang diikuti huruf sama pada kolom sama menunjukkan tidak beda nyata pada taraf signifikasi 5\% Figures followed by the same letter in the same column, are not signigicantly different at $5 \%$

Gambar 2. Kadar karet kering pada berbagai sistem sadap

Figure 2. Dry rubber content at various tapping systems 


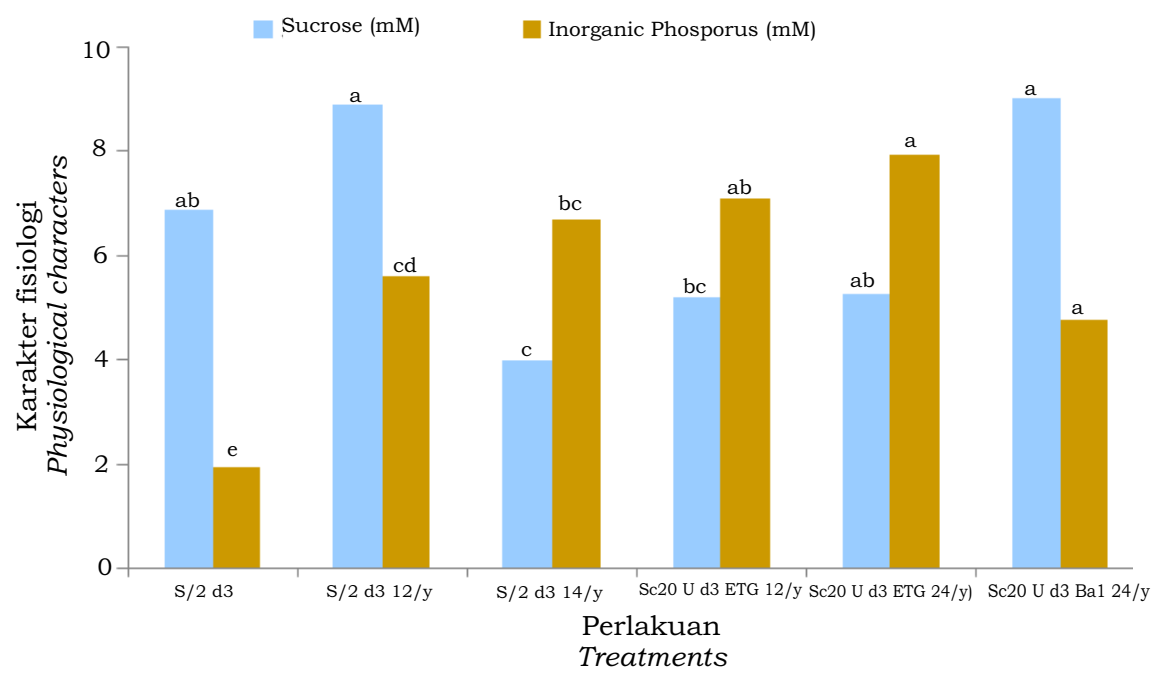

Angka yang diikuti huruf sama pada kolom sama menunjukkan tidak beda nyata pada taraf signifikasi $5 \%$ Figures followed by the same letter in the same column, are not signigicantly different at 5\%

Gambar 3. Berbagai karakter fisiologi pada berbagai sistem sadap Figure 3. Several physiological characters at various tapping systems
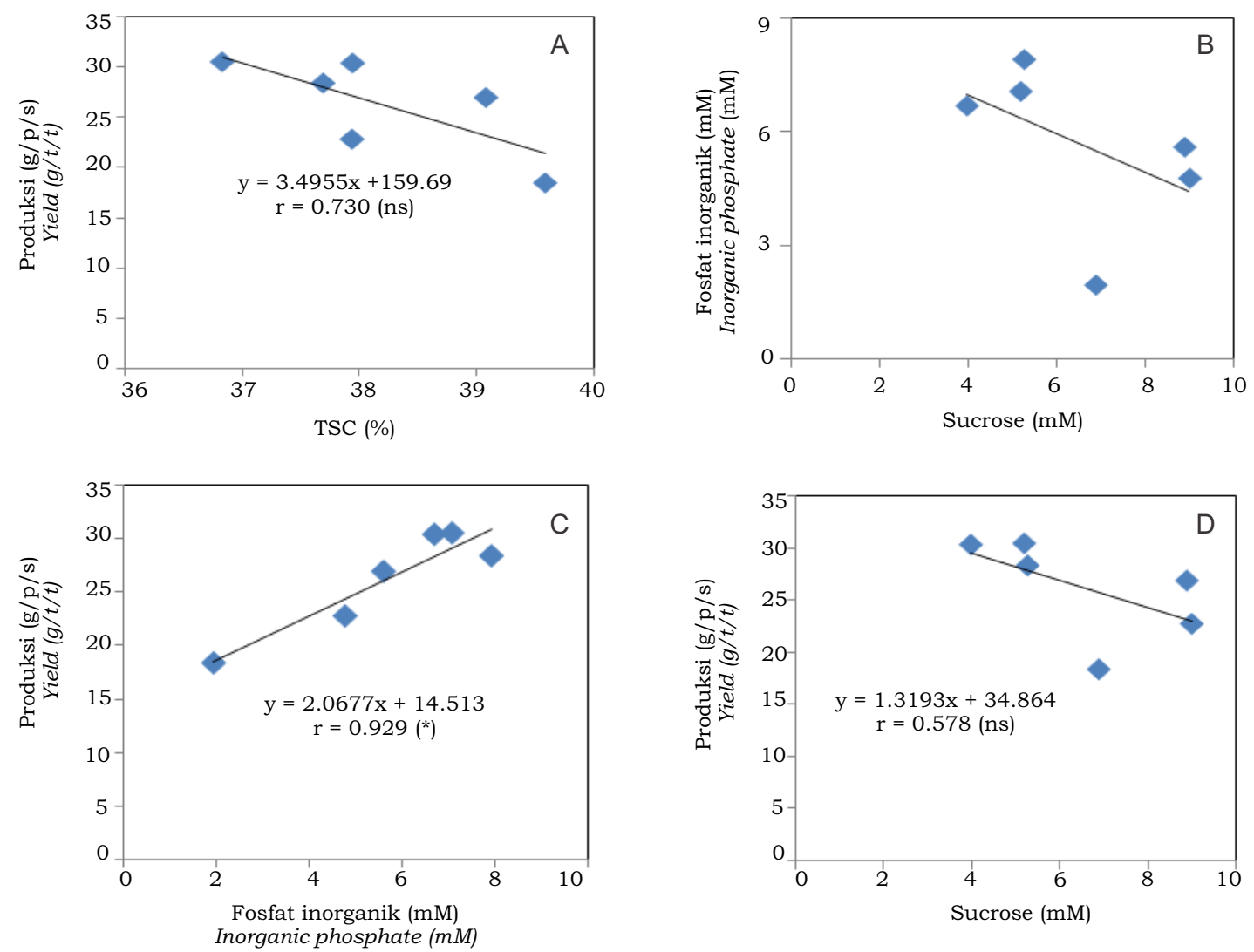

$\left(^{*}=\right.$ nyata $($ significant $), \mathrm{ns}=$ tidak nyata $($ not significant $)$

Gambar 4. Hubungan antara karakter fisiologi dan produksi Figure 4. Relationship between some physiological characters and yield 
Hal ini menandakan bahwa cadangan sukrosa pada panel sadap sedikit dan persediaan sukrosa dari floem tidak mencukupi (D'Auzac dan Jacob, 1984). Begitu juga dengan peningkatan frekuensi stimulan gas dari sekali per bulan menjadi dua kali per bulan tidak meningkatkan fosfat anorganik, tidak mempengaruhi sukrosa, dan berakibat tidak meningkatnya hasil.

Eksploitasi berlebihan pada tanaman karet dapat menyebabkan timbulnya kering alur sadap (KAS). Intensitas KAS pada alur sadap perlakuan kombinasi irisan pendek dengan stimulan gas lebih besar dibandingkan dengan irisan pendek dengan stimulan etefon, termasuk kategori 1 yang berarti intensitas KAS pada alur sadap tersebut masih relatif rendah $(<25 \%)$ (Tabel 1). Penggunaan stimulan gas dalam sistem sadap untuk jangka panjang perlu pertimbangan khusus agar tidak terjadi gangguan metabolisme dalam biosintesis lateks. Efek lanjut mengakibatkan kelelahan pembuluh lateks (Lacote et al., 2010; Krishnakumar et al., 2011).

Walaupun dengan sistem sadap irisan pendek ke arah atas memberikan produksi tinggi, namun kendala yang perlu dipertimbangkan adalah mutu sadapan yang biasanya kurang baik dan adanya kehilangan produksi. Konsumsi kulit untuk sistem sadap irisan pendek ke arah atas lebih tebal dua kali lipat dibandingkan dengan $\mathrm{S} / 2$, karena penyadap lebih sulit untuk mengontrol sadapan (Gambar 5A).

Tabel 1. Kategori kering alur sadap (KAS) pada berbagai perlakuan

Table 1. Category of tapping panel dryness at various treatments

\begin{tabular}{cc}
\hline \multicolumn{1}{c}{$\begin{array}{c}\text { Perlakuan } \\
\text { Treatment }\end{array}$} & $\begin{array}{c}\text { Kering alur sadap } \\
\text { Panel dryness }\end{array}$ \\
\hline $\mathrm{S} / 2 \mathrm{~d} 3$ (control) & 0 \\
$\mathrm{~S} / 2 \mathrm{~d} 3$ ET2,5\% Ga1 $12 / \mathrm{y}$ & 0 \\
$\mathrm{~S} / 2 \mathrm{~d} 3$ ET2,5\% Ga1 24/y & 0 \\
Sc20 U d3 ETG 12/y & 1 \\
Sc20 U d3 ETG 24/y & 1 \\
Se20 Ud3 ET Ba1 24/y & 0 \\
\hline
\end{tabular}

Kategori KAS (tapping panel dryness categories): $0 \%=0 ; 1-25 \%=1 ; 26-50 \%=2 ; 51-75 \%=3 ; 76-100 \%=4$
Keterampilan penyadap SKA lebih rendah dibanding keterampilan penyadap SKB. Usaha yang dapat dilakukan untuk mengatasi hal tersebut yaitu dengan melatih penyadap secara intensif dan terus-menerus sampai keterampilan penyadap SKA setara dengan keterampilan penyadap SKB. Begitu juga dengan aliran lateks yang seringkali keluar dari alur sadap dengan sistem sadap irisan pendek ke arah atas yang disebabkan sudut yang dihasilkan dari penyadapan kurang membentuk V (Gambar 5B), sehingga menimbulkan hilangnya produksi (Hashim, 1986).

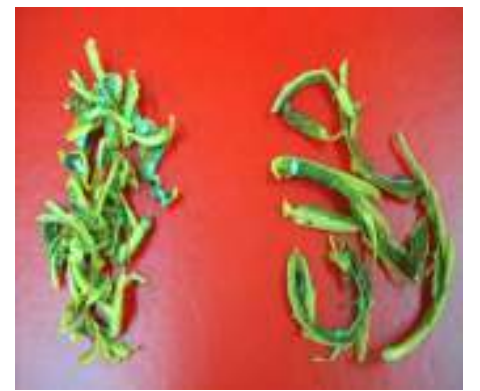

A

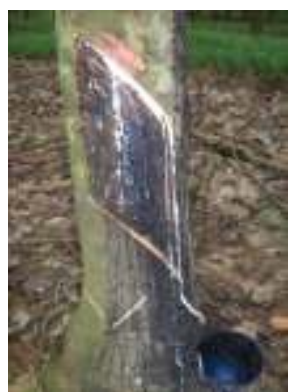

B
Gambar 5. Kendala penyadapan ke arah atas.

A) Perbandingan konsumsi kulit dua kali sistem sadap ke arah bawah

B) Tumpahnya lateks dari alur sadap

Figures 5. Some problems in upward tapping.

A) Bark consumption from doubles compared with the conventional tapping

B) Latex spille over the groove

\section{KESIMPULAN DAN SARAN}

Alternatif sistem sadap yang mampu meningkatkan produksi tan pa menimbulkan pengaruh negatif terhadap parameter fisiologi adalah S/2 d3 ET2,5\% Ga1 12/y (m) atau Sc20 U d3 ETG 12/y(m). Namun penggunaan stimulan gas pada tanaman muda perlu mempertimbangkan risiko kering alur sadap. Penyadapan ke arah atas memiliki kecenderungan lebih tebal dalam konsumsi kulit dan tumpahnya lateks dari alur sadap, penyadapnya sebaiknya dilatih dengan baik. 


\section{DAFTAR PUSTAKA}

Coupe, M. and H. Chrestin. 1989. Physicochemical and biochemical mechanism of hormonal (Ethylene) stimulation. In Physiology of Rubber Tree Latex. CRC Press

d'Auzac and J.L. Jacob. 1984. Physiology of the Laticiferus System in Hevea Basis and Application to Productivity. Compte-Rendu du Colloque : Exploitation and Physiology Amelioration. CRC Press, Perancis.

Dische, Z. M. 1962. Carbohydrate Chem. Acad. Press. 1.

Gohet, E., C. Scomparin, E. Cavaloc, Y. Balerin, G. Benites, F. Dumortier, H. Williams, H.P. Permadi, E. Ginting, E. De Rostolan, E. Uche, P. Chegbene, E. Hocepied, P. Echimane, M. Saumahoro, H.J. Sargeant, Suyatno, C.A. Najera, B. Saumahoro, R. Lacote, and J.M. Eschbach. 2008. Influence of Ethephon Stimulation on Latex Physiological Parameter and Conquences on Latex Diagnosis Implementation in Rubber AgroIndustry. IRRDB Workshop: Latex Harvesting Technology.

Gomez, J.B. 1983. Physiology of Latex (Rubber) Production. Malaysian Rubber Research and Development Board.

Hashim, I. 1986. Minimising Latex Spillage with Controlled Upward Tapping. Plr's. Bull. Rubb. Res., 189, 153-158.

Jacob, J.L., J.C. Prevot, D. Roussel, R. Lacrotte, E. Serres, J. dAuzac, J. M. Eschbach, and H. Omont. 1989. Field limiting factors, latex physiological parameters, latex diagnosis, and clonal typology. In Physiology of Rubber Tree Latex, CRC Press, Perancis.

Junaidi, U. and Kuswanhadi. 1995. Effect of upward tapping (UT) on rubber production of recommended Hevea clone. Indonesian J. Nat. Rubb. Res., 13 (2): 99-112.
Junaidi, U. and Kuswanhadi. 1997. Upward tapping system as an alternative to downward tapping system on recommended Hevea clones. Jurnal Penelitian Karet, 15 (1): 1- 12.

Krishnakumar, R., R.L. Helen, P.K. Ambily, and J. Jacob. 2011. A Modified Stimulation Method in Hevea brasiliensis for Reducing Oxidative Stress. IRRDB Inter. Rubb. Conf. 15 16 December 2011. Thailand.

Lacote, R., O. Gabla, S. Obouayeba, J.M. Eschbach, F. Rivano, K. Dian, and E. Gohet. 2010. Long term effect of ethylene stimulation on the yield of rubber trees is linked to latex cell biochemistry. Field Crops Research, 115, 94-98.

Lukman. 1995. Application of upward tapping (UT) with low exploitation intensity to increase yield and economic life of rubber trees.

Obouayeba, S., E.F. Soumahin, and A. Anno. 2008. Influence of the direction of the tapping cut lenght on the production parameters of the clones GT 1 and PB 235 of Hevea brasiliensis, in the southeast of Cote D'ivoire. IRRDB Natural Rubber Conference 2008. Malaysia 13-17 Oktober 2008.

Pakianathan, S.W., G. Haridas, and J. d'Auzac. 1989. Water relations and latex flow. In Physiology of Rubber Tree Latex, CRC Press Perancis

Sivakumaran, S., I. Hashim, and P.D. Abraham. 1985. The effect of direction of tapping and position of cut on yield responses to stimulation. J. Rubb. Res. Inst. Malaysia. 33 (2), 83-104.

Soumahin, E.F., S. Obouayeba, and P.A. Anno. 2009. Low tapping frequency with hormonal stimulation on Hevea brasiliensis clone PB 217 reduces tapping manpower requirement. $J$. Animal and Plant Sciences 2 ( 3): 109117. 
Southorn, W.A. and J.B. Gomez. 1970. Latex flow studies VII. Influence of lenght of tapping cut on latex flow pattern. $J$. Rubb. Res. Inst. Malaya 23 (1): 15-22.

Taussky, H.H. and E. Shorr. 1953. A micro colorimetric methods for the determination of inorganic phosphorus. J. Biol. Chem 202: 675685.
Van Gils, G.E. 1951. Studies on the viscosity of latex : influence of the dry rubber content. Arc. Rubbercult.

Wargadipura, R. 1981. Pengujian efikasi stimulan ethrel $2,5 \%$ ready mix pada tanaman karet. Menara Perkebunan, 49 (2): 31-35. 